Список литературы:

1. Российский государственный исторический архив. Ф. 880. Оп. 2. Д. 168.

2. Базиянц А.П. Лазаревский институт в истории отечественного востоковедения. М.: Издательство «Наука», 1973. 224 с.

3. Игнатян А.А. История Московского Лазаревского института восточных языков (арм.): дис. ... канд. пед. наук: 13.00.01. Ереван, 1969. 186 с.

4. Ананян Ж.А. Лазаревский институт восточных языков в контексте русского Просвещения // Человек эпохи Просвещения. 1999. № 4. С. 202-218.

5. Саядов С.М. Лазаревы и история армянского народа // Вторые Лазаревские чтения по истории армян России, 25-27 ноября 2003. М., 2006. С. 191-200.

6. Зиновьев А. Исторический очерк Лазаревского института восточных языков с краткой биографией учредителей института. СПб.: Тип. Императорской академии наук, $1855.149 \mathrm{c}$.

7. Братская помощь пострадавшим в Турции армянам. М., 1898.940 с.

8. Российский государственный архив древних актов (РГАДА). Ф. 1252. Оп. 1. Д. 331.

9. Материалы для истории Лазаревского Института восточных языков, издаваемые иждивением г. попечителя князя Семена Семеновича АбамелекЛазарева. М., 1914. Вып. 1. 20 с.

10. РГАДА. Ф. 1252. Оп. 1. Д. 262.

11. Кананов Г.И. Семидесятипятилетие Лазаревского Института восточных языков. 1815-1850 гг. М.: Тип. А.А. Гатцука, 1891. 256 с.

12. Дмитриев А.А. Пермские земледельцы Лазаревы и их преемники князья Абамелеки // Исторический вестник. 1893. Т. 52, № 5. С. 425-447.

13. РГАДА. Ф. 1252. Оп. 1. Д. 263.

14. РГАДА. Ф. 1252. Оп. 1. Д. 300.

15. РГАДА. Ф. 1252. Оп. 1. Д. 17.

16. РГАДА. Ф. 1252. Оп. 1. Д. 390.

17. Полное собрание законов Российской империи. СПб., 1841. Т. 16, № 14235.924 с.

18. Высочайше утвержденный устав Лазаревского института восточных языков // Полное собрание законов Российской империи. СПб., 1875. Собрание 2е. Т. 47. Ч. 2. № 51655.1276 c.

19. Центральный государственный архив Москвы (ЦГАМ). Ф. 213. Оп. 1. Д. 98.

20. Собрание актов, относящихся к обозрению истории армянского народа. М.: Типография Лазаревского института восточных языков, 1838. Ч. ІІІ. 458 с.

21. ЦГАМ. Ф. 213. Оп. 1. Д. 7.

\title{
PARTICIPATION OF THE ARMENIAN APOSTOLIC CHURCH IN THE EDUCATIONAL AND ADMINISTRATIVE ACTIVITIES OF LAZAREV INSTITUTE OF ORIENTAL LANGUAGES
} (C) 2019

Avetisyan Vladimir Rudolfovich, candidate of historical sciences, head of Publication Department State Archive of the Stavropol Krai (Stavropol, Russian Federation)

Abstract. The Institute of Oriental Languages (Lazarev Institute) throughout its existence (1815-1921) has undergone a number of transformations, namely, having started its activity from a private school, it achieved the status of a state higher educational institution. Understanding a special role of religion in preserving the ethnic characteristics of the Armenian nation in the absence of statehood, prominent Russian public and state figures of Lazarev contributed to strengthening the status of the church within the walls of the institute. Representatives of the Armenian Apostolic Church (AAC) provided all possible assistance to the educational process, first at school, and then at the institute. The apogee in 1841 became the legal consolidation of the rights of the AAC to directly participate in leading the institute and obtaining the status of the honorary member of the institute by the Catholicos. Many Armenian clergies have made a significant contribution to the development of the educational institution, acting as a guarantor of the cultural foundations of the Armenian people. With the assistance of the church, new directions acted at the Lazarev Institute, scholarships were established, and literature was published. The materials obtained during the research can serve as a basis for further studying the role of church organizations in the educational life of secondary and higher educational institutions of the country.

Keywords: Armenian Apostolic Church; Armenian Gregorian Church; Lazarev Institute of Oriental Languages; Armenian Moscow School; Lazarev; education; spiritual department; special classes; church scholarships; Armenian community; Moscow; Catholicos of All Armenians Efrem; patriarch Nerses.

УДК 343.812 (091) (470.56)

DOI $10.24411 / 2309-4370-2019-11206$

Статья поступила в редакцию 12.01.2019

\section{ОБЩЕУГОЛОВНЫЕ ТЮРЬМЫ РОССИЙСКОМ ИМПЕРИИ В ХІХ ВЕКЕ (НА ПРИМЕРЕ ОРЕНБУРГСКОЙ ГУБЕРНИИ)}

(C) 2019

Кузнецова Юлия Владимировна, кандидат исторических наук, доцент кафедры истории и философии Оренбургский государственный аграрный университет (г. Оренбург, Российская Федерачия)

Аннотащия. В статье предпринята попытка на основе архивных и опубликованных материалов дать краткую характеристику состояния общеуголовных тюрем Российской империи в XIX в. на примере Оренбургской губернии. В первой половине XIX веке многие тюремные здания находились в ветхом состоянии, при этом большинство из них были деревянные. Заключённые страдали от перенаселения камер, не разделялись по полу и возрасту, больные содержались вместе со здоровыми, голодали, жили подаянием. Очень часто помещениями для тюрем служили частные наёмные дома. Медицинский персонал в тюрьмах отсутствовал, случались 
эпидемии, приводившие к громадному росту смертности. Что касается работы, то в первой половине XIX века в тюремных замках и острогах она для арестантов вводилась в самых редких случаях, так как для этого не было специальных помещений. В пореформенный период многие тюремные помещения были отремонтированы, под больницы стали арендовывать помещения, улучшился рацион заключённых, в 80-х гг. ХІХ в. была введена плата за арестантский труд, улучшилась просветительская деятельность в тюрьмах. Несмотря на принятые со стороны правительства меры, состояние общеуголовных тюрем на Южном Урале на протяжении всего XIX в. попрежнему оставалось плачевным по причине того, что не хватало денежных средств либо местная администрация не была заинтересована в улучшении положения арестантов и самого состояния тюрем.

Ключевые слова: арестант; Верхнеуральский тюремный замок; ветхое состояние; XIX век; историография; камера; медицинский персонал; местная администрация; общеуголовные тюрьмы; Оренбургская губерния; Оренбургский тюремный замок; острог; пенитенциарная система; правительство; Российская империя; труд арестантов; тюремный замок; эпидемии.

Российское государство имеет богатый опыт развития уголовно-исполнительной системы, который можно использовать в процессе подготовки и проведения реформ на современном этапе. Одной из составляющих этой системы является тюремная политика. Именно поэтому изучение истории общеуголовных тюрем Российской империи в XIX в. является актуальным. Автор считает также весьма актуальной задачу обобщения и введения в научный оборот ранее не использованного и не опубликованного архивного материала по истории общеуголовных тюрем Оренбургской области.

В историографическом анализе темы условно можно обозначить три основных периода развития литературы по исследуемой проблеме: дореволюционный, советский, постсоветский. Исследования, посвящённые анализу и истории пенитенциарной системы в дореволюционное время, выполнялись в русле работ, посвящённых уголовному праву [1-8].

В целом следует отметить, что главная особенность дореволюционной историографии пенитенциарной системы Российской империи в том, что она представлена в основном учёными-юристами и правоведами. Но они характеризуют разные стороны этой системы достаточно подробно.

На региональном уровне вопросы истории общеуголовных тюрем учёные практически не затрагивали.

Что касается советской историографии, посвящённой истории общеуголовных тюрем, то следует отметить, что эта тема мало изучалась. С 1921 г. по 1935 г. данная тема освещалась на страницах журнала «Каторга и ссылка». Авторы статей особое внимание уделяли освещению судьбы политических заключённых-революционеров. С 1935 г. история пенитенциарной системы России XIX в. практически не изучалась. После окончания Великой Отечественной войны вышел фундаментальный труд М.Н. Гернета «История царской тюрьмы» в 5 томах [9-11]. В своём пятитомном исследовании автор дал историю всех видов тюрем и сведения о многих политических процессах (о декабристах, петрашевцах). В этом труде даётся очень подробное описание тюремного режима, состояние отдельных тюрем в те или иные годы. В целом Гернет отрицательно отзывается о состоянии тюрем, тюремного режима. Однако сведения об общеуголовных тюрьмах Оренбургской губернии практически отсутствуют.

После выхода монографии М.Н. Гернета наступило «затишье» в изучении данной темы. Лишь с 1970 г. историки снова начали публиковать свои труды по данной теме [12-15].

В публикациях и диссертациях 1990-2000-х гг. авторы на основе большой источниковедческой базы освещали историю тех или иных видов тюрем и активно обобщали материал как на уровне отдельных регионов, так и Российской империи в целом [16-23].

Следует отметить монографию Б.Н. Миронова «Социальная история России периода империи (XVIII - начало XX в.)» [24]. Здесь автор рассматривает, во-первых, историю уголовного законодательства, во-вторых, влияние тех или иных законов на уровень преступности, в-третьих, пенитенциарную систему Российской империи. Вместе с тем, так как изучение российских тюрем не было его главной задачей, вопрос этот освещён кратко и обзорно.

Следует обратить внимание на работы и оренбургских историков [25-29]. Из них можно почерпнуть данные по теме данной статьи.

Таким образом, можно сделать вывод, что исторической литературы по данной теме очень много. История общеуголовных тюрем Российской империи в XIX веке на примере Оренбургской губернии не нашла в них необходимой разработки.

В общеуголовных тюрьмах содержались лица, совершившие различные преступления. В начале XIX века заключённые по-прежнему, так же как и в XVIII веке, в большинстве мест заключения страдали от перенаселения камер, не разделялись по полу и возрасту, больные содержались вместе со здоровыми, им не хватало продуктов питания. От голода очень часто спасали подаяния. Медицинские кадры в тюрьмах отсутствовали, поэтому эпидемии приводили к случаям летальных исходов среди заключённых [24, c. 33].

Аналогичной была ситуация и в странах Европы и США. В их тюрьмах было очень много инфекций, в связи с тем, что большое количество арестантов находилось в плохо вентилируемых помещениях. В камерах царила антисанитария, заключённые получали некачественную пищу. Недостаток медицинских препаратов способствовал высокой смертности среди арестантов.

Состояние многих тюрем было ветхим. Многие тюремные здания были деревянными. Так, в 1820 году военному губернатору Оренбургской губернии правительство направило предписание, в котором говорилось, что необходимо принять меры к исправлению ветхости тюремных изб в Стерлитамаке, Белебее, Бузулуке, так как оттуда совершают побеги арестанты [30, л. 8 об.].

С 1821 г. стали приниматься меры: теперь у деревянных замков имелся каменный фундамент и железные решётки на окнах. Такие замки находились в Стерлитамаке, Бирске, Мензелинске, Бузулуке, Бугуруслане, Челябинске, Троицке, Верхнеуральске. 
Всего было истрачено 209 тыс. 700 руб. 71 коп. В Бугульме и Белебее были построены каменные замки, потому что не хватало соснового леса. На них истратили 124 тыс. 20 руб. 75 коп. [30, л. 9 об.]. В этом же году в городе Уральске был построен ещё один тюремный замок. Казармы были разделены на четыре отделения по родам преступлений:

1) для содержания важных преступников;

2) для воров, беглецов;

3) для подозревающихся в преступлениях, но не раскрытых следствием;

4) для лиц женского пола [30, л. 1 об.].

Следует отметить, что это положительно сказалось на заключении арестантов, так как была ликвидирована теснота в камерах. В зданиях старых казарм устроили баню и кухню $[30$, л. 6].

Несмотря на отмеченные частичные улучшения, лишь с 30-х годов XIX века правительство начинает знакомиться с состоянием общеуголовных тюрем. До этого времени оно носило случайный характер или, правильнее сказать, совсем не имело места. Тюрьмы осматривали ревизоры, флигель-адъютанты, губернаторы, чиновники. Но данные меры не улучшили состояние общеуголовных тюрем. [10, с. 434]. К примеру, в 1833-1834 гг. в Оренбургской губернии здания тюрем в Белебее, Бугуруслане, Бузулуке, Челябинске, Троицке, несмотря на частные починки, едва могли содержать в себе арестантов, почти каждый день угрожали падением. Из Верхнеуральской тюрьмы арестантов перевели в гауптвахту. В Белебее, Мензелинске правительство разрешило купить для арестантов частные дома. В лучшем состоянии находился Уфимский тюремный замок, потому что он находился на виду у губернского начальства и ежегодно ремонтировался [31, л. 6].

В 1840-х годах по-прежнему поступали сведения от местных властей о тяжёлом положении в тюремной сфере [32, л. 25-28]. В июле 1842 г. циркуляр Главного управления путей сообщения и публичных зданий утвердил топку печей из коридоров (они топились дровами) [10, с. 441]. Данная мера отрицательно сказывалась на температуре в камерах. Хотя до выхода данного циркуляра во многих тюрьмах топки печей были устроены внутри камер.

Что касается состояния здоровья арестантов, то следует отметить, что больные не только не содержались в камерах, но и лежали на одних койках со здоровыми заключёнными. В Оренбургской губернии только в 1834 г. при Уфимском тюремном замке открыли больницу на двадцать четыре койки. Другие тюрьмы губернии больниц не имели [31, л. 15].

Не удивительно, что при таких условиях эпидемии в тюрьмах распространялись очень быстро. Этому способствовало и плохое питание. В некоторых тюремных замках, благодаря деятельности тюремных комитетов, действовавших на основании правил Попечительного общества о тюрьмах, арестанты получали хорошую пищу. К примеру, ежедневно в Уфимском и Оренбургском тюремных замках арестанты получали квас, щи из капусты, кашу из крупы или гороха с маслом, хлеба по два с половиной фунта на каждого [33, л. 195-196 об.].

Практически таким же был рацион арестантов и в Англии. За исключением того, что английские заключённые получали какао.
Нередко благотворительность людей облегчала положение заключённых. В России она была в единичных случаях, а на Западе приобрела значительные масштабы.

В выходные или праздничные дни арестанты Уфимского и Оренбургского тюремных замков получали рыбу и говядину по 0,5 фунта на каждого. То есть, из вышесказанного видно, что деятельность тюремных комитетов облегчала положение заключённых [33, л. 199].

Не в лучшем состоянии были и санитарные условия содержания заключённых. В баню арестантам позволяли ходить редко. В некоторых тюрьмах бани вообще отсутствовали. Лишь изредка арестанты получали небольшое количество горячей воды и маленький кусочек мыла [10, с. 443].

Отвлечением от серых будней служили придуманные ими «игры»: например, охота на насекомыхпаразитов (вшей, клопов), игра в «ложки» (битьё друг друга деревянными ложками по оголённому животу) и другие игры $[10$, с. 446]. Конечно же, все эти развлечения носили грязный, противоестественный, аморальный характер.

Использование труда арестантов в первой половине XIX века практиковалось крайне редко, потому что в тюрьмах не было специальных помещений. Отсутствие работы оказывало отрицательное влияние на психическое и физическое здоровье арестантов [10, c. 380].

В Европе же, наоборот, труд заключённых практиковался часто. Это можно рассмотреть на примере Англии. Заключённые работали с шести утра и до семи вечера. Работа была всегда тяжёлой и изматывающей.

В указанный период времени переполняемость общеуголовных тюрем решали следующем образом: заменяли тюремное заключение отдачей в солдаты. Заключённому не должно было быть больше тридцати пяти лет. Арестантов семи-девяти лет отправляли в кантонисты, а семнадцатилетних - в солдаты. Осуждённых за тяжёлые преступления не имели право отдавать в солдаты [10, с. 380$]$.

Итак, следует сказать, что ходатайства местных властей с просьбой о ремонтах тюрем и острогов чаще всего игнорировались центральным правительством, или выделенных денег не хватало на ремонт. Встречались случаи и разворовывания денег на местах. Этим и объясняется ветхость тюрем и плохие условия содержания арестантов.

Во второй половине XIX века кардинальных изменений в тюремной сфере Российской империи не произошло. Об этом свидетельствует отчёт 1866 года о состоянии тюрем в Оренбургской губернии: «В Троицке - содержание помещения неопрятное, камеры переполнены, так что не всем есть место на нарах и многие валяются на полу. В Челябе замок тоже ветхий, в окнах выбиты стёкла, в дверях такое отверстие для наблюдения за арестантами, которое для устрашения сквозного ветра заложено тряпьём и заклеено бумагой. В Верхнеуральске тюрьма помещена в строении крайне ветхом, много выбито стёкол. Это может повлечь побег» [34, л. 1-5 об.].

Такое состояние тюрем объясняется тем, что тюремный бюджет государства был дефицитным [11, c. 386]. Из-за нехватки денег не могли построить и 
дополнительных камер в тюрьмах, поэтому в камерах было очень тесно. Так, к примеру, в 1888 году в Оренбургском тюремном замке находилось в одной камере по тридцать человек, хотя норма была - десять, то есть в три раза меньше, поэтому заключённые спали под нарами, а некоторых выводили в столовую и на кухню [34, л. 10 об.].

Нередко из-за отсутствия тюремных помещений под них использовали частные наёмные дома. Например, в 1888 году в Верхнеуральском тюремном замке Оренбургской губернии содержалось 178 арестантов, а он был построен на 56 человек, поэтому наняли дополнительные помещения за двести рублей в год. Администрация Челябинского тюремного замка тоже была вынуждена арендовать три помещения у чиновника, одно у купца [35, л. 4].

Нехватка денег отрицательно сказывалась и на питании заключённых. В год на каждого арестанта правительство выделяло всего сорок рублей, то есть в месяц получалось три рубля с полтиной [11, с. 34]. A, к примеру, священнику, находившемуся при Оренбургском тюремном замке, платили триста шестьдесят рублей в год, то есть тридцать рублей в месяц [36, л. 189].

Для улучшения рациона арестантов при некоторых тюрьмах стали сажать огороды. В частности, огород Оренбургского тюремного замка в 1890 году находился вблизи завода Хусаинова [37, л. 134]. На огородах работали сами арестанты.

Лишь только с 1886 года правительство стало беспокоиться вопросом организации работ среди арестантов. Теперь они должны были обязательно трудиться и получать денежное вознаграждение. Высокой производительности труда мешало отсутствие помещений, приспособленных для работы, инструментов и сырья, а также маленький спрос на арестантский труд. Именно поэтому арестанты в основном очищали улицы города, отхожие места, пилили дрова. Внутри тюрем арестанты ремонтировали обувь и занимались столярными работами. Так, в отчёте за 1888 год пишется, что при Оренбургском тюремном замке мастерских не было, поэтому работы проводились в камерах, при Орском тюремном замке и при Верхнеуральском их тоже не было. Мастерские были только при Троицкой тюрьме. Арестанты этих тюрем так же, как и в других тюрьмах, занимались починкой обуви, одежды, очисткой дворов, пилили дрова. Иногда их нанимала Городская управа для занятия какими-либо работами, например, для очистки городских улиц. За побеги арестантов с работы устанавливалась круговая порука [37, л. 199].

В Англии и Ирландии в указанный период времени заключённые так же, как и в Российской империи, занимались ремёслами.

Своеобразная организация труда заключённых практиковалась в США после завершения Гражданской войны. Заключённые-северяне трудились в тюремных мастерских, а заключённых-южан отдавали в аренду на работы на плантациях. Содержание и охрану сидельцев брали на себя хозяева плантаций. В 1887 году конгресс США попытался запретить продавать труд федеральных заключённых, что вызвало недовольство штатов.

С 1891 года в США стали создаваться федеральные тюрьмы, в которых отбывали наказание пре- ступники, осуждённые за нарушения федеральных законов. Остальные же продолжали трудиться на плантациях и особых тюремных фермах.

Таким образом, следует отметить, что в общеуголовных тюрьмах Российской империи была крайне плохая постановка труда арестантов, в отличие от пенитенциарных учреждений стран Европы и США.

В тюрьмах Российской империи во второй половине XIX в. отсутствовали больницы. Единственным новшеством было то, что некоторые тюремные больницы стали помещать в наёмных домах. Например, больница Челябинской тюрьмы Оренбургской губернии находилась в доме купца. Иногда больных арестантов отправляли лечиться в городские больницы, как это было в Орской тюрьме (отправляли в Орский военный лазарет, лечение было платным) [35, л. 27 об.].

Со второй половины XIX века начинает активно проводиться просветительская деятельность в тюрьмах. Она сводилась к исполнению обрядов по правилам господствовавшей православной церкви. Для отправления богослужений при некоторых тюремных замках имелись церкви. Так, при Оренбургском тюремном замке в 1889 году имелась церковь во имя Святой Великомученицы Варвары [36, л. 34]. Если же церкви не было, то богослужение проводилось в камерах или конторах тюрьмы [36, л. 34].

В целом, если подвести итог состоянию общеуголовных тюрем за весь XIX век, то можно сказать, что они находились в самом плачевном состоянии. Конечно же, со стороны правительства были попытки улучшения положения арестантов в них (выделялись деньги на ремонт тюрем, на аренду помещений для заключённых), но на это либо выделялось мало средств, либо местная администрация не была заинтересована в улучшении положения арестантов и самого состояния тюрем.

\section{Список литературы:}

1. Познышев С.В. Очерки тюрьмоведения. М.: Г.А. Леман и Б.Д. Плетнев, 1915. 302 с.

2. Фойницкий Н.Я. Русская карательная система. СПб.: Гос. тип., 1874. 73 с.

3. Фойницкий Н.Я. Учение о наказании в связи с тюрьмоведением. СПб.: Тип. м-ва пут. сообщ. (А. Бенке), 1889. 514 с.

4. Таганцев Н.С. Русское уголовное право: в 2 т. СПб.: Гос. тип., 1902. Т. 2. 1089 с.

5. Сергеевский Н.Д. Наказание в русском праве XVII века. СПб.: Издание книжного магазина А.Ф. Цинзерлинга, 1887. 300 с.

6. Сергеевич В.Н. Лекции по истории русского права. СПб.: Типография М.М. Стасюлевича, 1890. $126 \mathrm{c}$.

7. Краинский Д.В. Материалы к исследованию истории русских тюрем. Чернигов: Тип. Губернск. Земства, 1912. 133 с.

8. Никитин В.Н. Тюрьма и ссылка. История законодательства, административного и бытового положения заключенных со времени возникновения русской тюрьмы до наших дней (1560-1880 гг.). СПб.: Тип. Г. Шпарварт, 1880. 134 с.

9. Гернет М.Н. История царской тюрьмы: в 5 т. М.: Наука, 1946. Т. 2. 456 с.

10. Гернет М.Н. История царской тюрьмы: в 5 т. М.: Наука, 1946. Т. 3. 500 с. 
11. Гернет М.Н. История царской тюрьмы: в 5 т. М.: Наука, 1946. Т. 4. 478 с.

12. Воробейчикова Т.У., Дубровина А.Б. Преобразования административно-полицейского аппарата, суда и тюремной системы России во второй половине XIX века. Киев: Слово, 1973. 237 с.

13. Смольяков В.Г. Тюремная система дореволюционной России, ее реакционная сущность. М.: Акад. МВД СССР, 1979. $38 \mathrm{c}$.

14. Гайдук С.А. Тюремная политика и тюремное законодательство пореформенной России: автореф. дис. ... канд. юрид. наук. М., 1987. 18 с.

15. Детков М.Г. Исполнение наказания в дореволюционной России: организационно-правовые аспекты становления и развития системы исполнения наказания в виде лишения свободы: учебное пособие. М.: ВНИИ МВД СССР, 1990. 85 с.

16. Пирогов П.П. Тюремная система Российской империи и ее кадровое обеспечение в XIX - начале XX вв.: автореф. дис. ... канд. ист. наук. СПб., 2000. $23 \mathrm{c}$.

17. Лисин А.Г., Петренко Н.И., Яковлева Е.И. Тюремная система Российского государства в XVIII начале XX вв. М.: Академия МВД, 1996. 60 с.

18. Фост Д. 30 «кошек» для ЗБХ. Монастырские тюрьмы. Увещание и исправление // Родина. 2006. № 8. C. 33-38.

19. Упоров И.В. Пенитенциарная политика России в XVIII-XX вв.: историко-правовой анализ тенденций развития. СПб.: Юрид. центр, 2004. 648 с.

20. Шебалков С.В. Организационное устройство мест заключения и система тюремного управления в Российской империи в конце XIX - начале XX вв. // Молодой ученый. 2013. № 10. С. 456-460.

21. Коняев А.Е. Тюремные учреждения Европейской России в 1879-1917 гг.: социально-экономический аспект деятельности (по материалам Ярославской и Владимирской губерний): автореф. дис. ... канд. ист. наук. Ярославль, 2010. 22 с.

22. Коломенцев Д.В. Тюремная система России в 50-80-е годы XIX века и ее реформирование: автореф. дис. ... канд. ист. наук. Воронеж, 2004. 20 с.
23. Асриев А.Ш., Усанов В.И. Тюремная реформа в России и тюрьмы Южного Зауралья в конце XIX начале XX вв. // Методология, теория и история государственно-правового регулирования. 2011. № 1(15). C. 4-14.

24. Миронов Б.Н. Социальная история России периода империи: в 2 т. М.: Просвещение, 2000. Т. 2. $657 \mathrm{c}$.

25. Осипов М.В. Тюремная реформа 1879 года и ее реализация в Оренбургской губернии: автореф. дис. ... канд. ист. наук. Оренбург, 2010. 24 с.

26. Ахтямов К.Ш., З Злобин Ю.П. Оренбургская полиция во второй половине XIX - начале XX вв. // История УВД Оренбургской области / под ред. Д.А. Сафонова. Оренбург: ОГПУ, 2002. С. 29-47.

27. Мокроносова О.М. Благотворительные организации во второй половине XIX - начале XX вв.: на материалах Южного Урала: автореф. дис. ... канд. ист. наук. Оренбург, 2002. 24 с.

28. Любичанковский С.В., Осипов М.В. Региональное бюрократическое сообщество в условиях модернизации государственного аппарата позднеимперской России (на примере тюремных преобразований в Оренбургской губернии в 1890-х гг. // Клио. 2011. № 9 (60). С. 74-77.

29. Любичанковский С.В., Осипов М.В. Реализация «великих реформ» на территории «внутренней периферии» Российской империи (на примере тюремных преобразований в Оренбургской губернии в 1870-1880-х гг.) // Вісник Чернігівського національного педагогічного університету імені Т.Г. Шевченка. Серія: Історичні науки. 2011. № 87. С. 126-129.

30. Государственный архив Оренбургской области (ГАОО). Ф. 6. Оп. 3. Д. 7140.

31. ГАОО. Ф. 6. Оп. 55. Д. 1108.

32. ГАОО. Ф. 6. Оп. 6. Д. 13.

33. ГАОО. Ф. 6. Оп. 59. Д. 11082.

34. ГАОО. Ф. 6. Оп. 19. Д. 623.

35. ГАОО. Ф. 134. Оп. 2. Д. 37.

36. ГАОО. Ф. 134. Оп. 1. Д. 46.

37. ГАОО. Ф. 6. Оп. 60. Д. 2080.

\title{
GENERAL-CRIMINAL PRISONS OF THE RUSSIAN EMPIRE IN THE XIX CENTURY (ON THE EXAMPLE OF THE ORENBURG PROVINCE)
}

(C) 2019

\author{
Kuznetsova Yulia Vladimirovna, candidate of historical sciences, \\ associate professor of History and Philosophy Department \\ Orenburg State Agrarian University (Orenburg, Russian Federation)
}

\begin{abstract}
The paper attempts to provide, on the basis of archival and published materials, a brief description of the state of general prisons in the Russian Empire in the $19^{\text {th }}$ century on the example of the Orenburg province. In the first half of the XIX century, many prison buildings were in a dilapidated state, most of them were wooden. The prisoners suffered from overcrowding, they were not separated by sex and age, the sick were kept together with the healthy ones, they were hungry, they lived in begging. Very often the premises for prisons were private rental houses. There were no medical personnel in prisons, there were epidemics that led to a huge increase in mortality. As for the work, in the first half of the XIX century in prison locks and guards it was introduced in the rarest cases, since there were no special rooms for this. In the post-reform period, many prison premises were repaired, premises began to be rented for hospitals, the prisoners' diet improved in the 1980s. The payment for arrest labor was introduced, the «educational» activity in prisons improved. Despite the measures taken by the government, the state of ordinary prisons in the southern Urals throughout the XIX century was still deplorable due to the fact that there was not enough money, or the local administration was not interested in improving the situation of the prisoners and the state of the prisons themselves.

Keywords: prisoner; Verkhneuralsky prison lock; dilapidated condition; XIX century; historiography; camera; medical staff; local administration; ordinary prisons; Orenburg Province; Orenburg prison castle; prison; penitentiary system; government; Russian empire; work of prisoners; prison lock; epidemic.
\end{abstract}

